\title{
Role of Media and Academic Journal in Providing the Evidence to Solve Child's Malnutrition in Indonesia
}

\author{
Tasnim Tasnim \\ STIKES Mandala Waluya Kendari \\ Jalan H.A Nasution No. G-37 Kambu, Kota Kendari, Sulawesi Tenggara 93232 \\ Corresponding author: tasnim349@gmail.com
}

\begin{abstract}
Background: Malnutrition in children under five is a serious public problem in Indonesia. Decision makers needed the evidences to overcome Indonesian children's malnutrition. Media and academic literatures could provide those. Objectives: This case study aimed to analyse the role between mass media and academic journal in providing the evidence to solve child's malnutrition in Indonesia. Methods: This case study selected 3 forms of media, including national newspapers, magazines and television. While, academic literatures were searched through Proquest database and Google scholar from 2006 until now. Results: This study found that both academic literatures and media have suggested the basic causes of child malnutrition such as economic deprivation, low parental education, contradictory local traditional beliefs and long drought. The causes then influenced households in purchasing power for food, providing appropriate foods, housing condition, utilization of child health care, parental awareness and knowledge about child nutrition. Eventually, these led to high child morbidity, low birth weight and low child nutritional intake. Conclusion: All information about malnutrition causes is available in both mass media and academic journal, but their presentation is different. Those sources are important and complementary.
\end{abstract}

Keywords: Media, Academic Journal, Evidence, Child, Malnutrition

\section{INTRODUCTION}

Malnutrition in children under five is a serious public health problem in Asia, including Indonesia. The prevalence of underweight children under five in Indonesia was $19.6 \%$ in 2010, compared to Thailand, Bhutan, China and Singapore were $7.0 \%, 12.0 \%$, $4.5 \%$ and 3.3\%, respectively Indonesian Health Department, 2011). Child malnutrition contributed to $1.7 \%$ to infant mortality rate in Indonesia (Indonesian Health Department, 2011). Infant mortality rate in Indonesia continues to rise. It rose from 28 per 1000 live births in 2006 to 34 per 1000 live births in 2010 (Indonesian Health Department, 2011). Furthermore, malnutrition in early childhood can increase impaired psychological and intellectual development that can lead to low school performance ( $\mathrm{Li}, 2009)$. This study compared the way to present the causes of child malnutrition in academic literature and in media. Selection of media and academic literatures will be described. This study also assessed the use of evidence, frameworks and research data in each. Furthermore, the role of media in relation to this topic was evaluated.

\section{METHOD}

This case study selected 3 forms of media, including a national newspaper, magazine and television. A selected national newspaper was The Jakarta Post. While, a proxy of a magazine was Tempo and Metrotvnews was a proxy of a television station. These three selected media were highly reputable and well-known in local, national and 
international areas. These media presented scientific news and provide electronic articles in the website. While, the academic literatures were searched through Proquest database and Google scholar. Both Proquest database and Google scholar gives big chances to find the academic papers from Indonesia in relation to this topic. Searching was limited to the start date of publication of 2006 until now. The reason is that in 2006, child morbidity and child malnutrition increased (Nurmiati \& Besral, 2008). Screening articles was based on the inclusion criteria, including the causes of malnutrition in children under five year of age in Indonesia. The terms that were used to search articles were "malnutrition" OR "child malnutrition" AND "children under five" AND "causes" AND "Indonesia". The first screening got 25 articles in The Jakarta Post, 11 articles in Tempo magazine and 10 articles in Metrotvnews. While, the first screening in Proquest database and Google scholar obtained 10 articles, because there were many same articles in both of them. After reading the full text on articles obtained 15 articles in The Jakarta Post, 8 articles in Tempo magazine, 7 articles in Metrotvnews and 8 articles of academic journals.

\section{Data Analysis}

This study used the framework of socio determinants of child malnutrition after Smith \& Haddad (Smith \& Haddad, 2000) To analyse the causes of child malnutrition that are presented by both academic journals and media. This model is more comprehensive because this model refers to the household economic model. Generally, this framework encompasses three level of causality, namely immediate, underlying and basic determinants of child malnutrition (Figure 1).

Figure1. The framework of socio determinants of child malnutrition

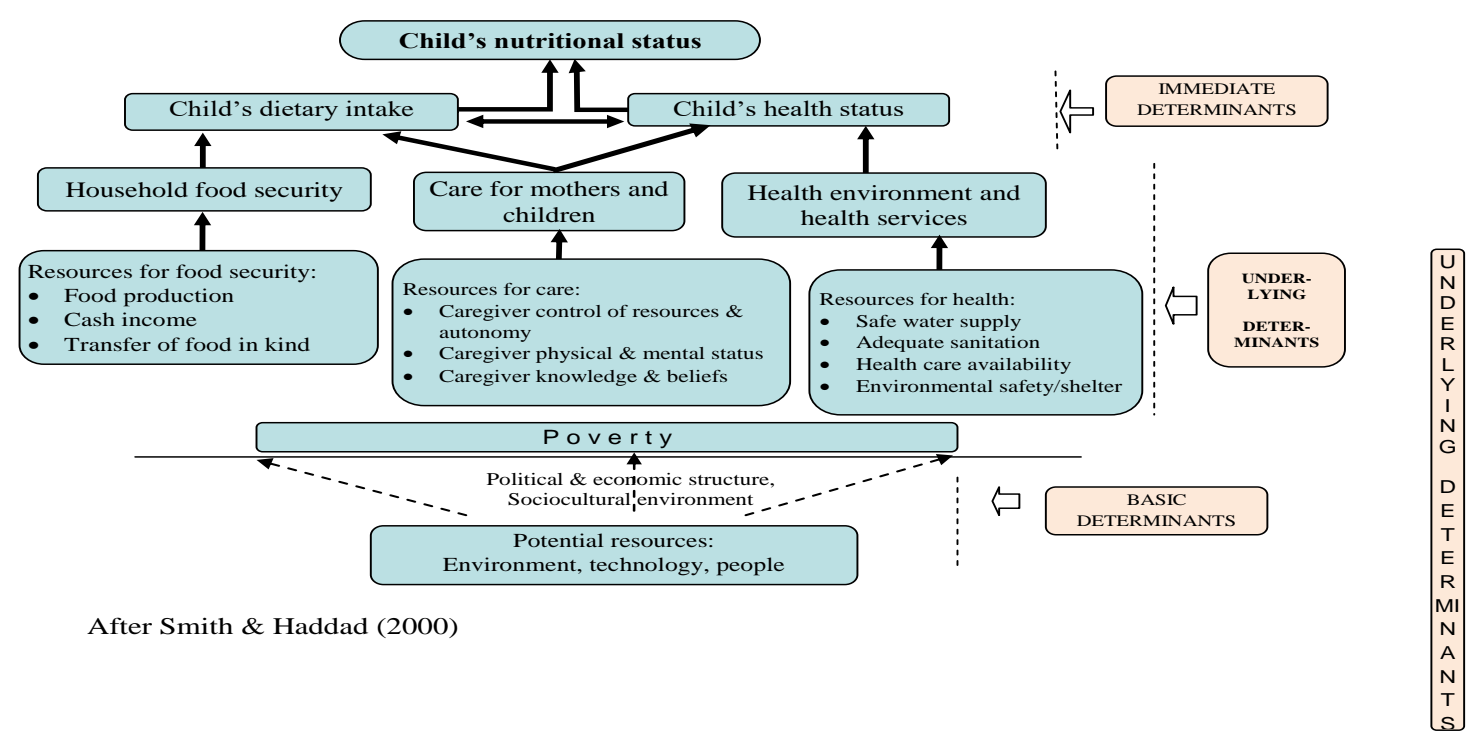

\section{RESULT AND DISCUSSION}

In general, both academic literatures and media presented economic deprivation, low parental formal education, contradictory local traditional beliefs and long drought as the basic causes of child malnutrition in Indonesia. Those factors then influenced availability for food, parental knowledge of nutrition, child feeding practices, providing housing and utilization to child health services. Ultimately, these underlying causes led to high child morbidity, low birth weight and low child nutritional intake. These three factors were immediate causes of child malnutrition in Indonesia. Providing valid evidence to support the public health issues is important to increase trustworthiness (Keleher \& 
MacDougall, 2011). The valid evidence is produced from a scientific study that uses rigour methods. Academic journals present scientific studies, so presenting of the causes of child malnutrition is supported with sufficient evidence rather than media. In contrast, media are viewed as the sender messages to persuade audiences toward particular behaviours. Thus, its messages become simple and highly influential. Academic journals use statistical evidence to support their arguments about the causes of child malnutrition. For example, Bardosono,. Sastroamidjojo and Lukito (2007) suggest that child morbidity contributes significantly to child wasting in urban poor area, such as Jakarta with the following equation WHZ $=-1.134-0.400$ Jakarta -0.194 Child morbidity. Other examples of the statistical evidence of the causes of child malnutrition can be seen in the table.

Table 1 Using the statistical evidence in academic journals

\begin{tabular}{lcc}
\hline \multicolumn{1}{c}{ The causes of child malnutrition } & \multicolumn{1}{c}{ The statistical evidence } & \multicolumn{1}{c}{ Authors } \\
\hline $\begin{array}{l}\text { Parental education and protective } \\
\text { behaviours }\end{array}$ & OR. 1.48, 95\%, CI (1.45-1.51) & Berger et al., 2007. \\
\hline $\begin{array}{l}\text { Maternal education and protective } \\
\text { behaviours }\end{array}$ & OR 1.65, 95\%, CI (1.62-1.69) & Berger, et al., 2007 \\
\hline $\begin{array}{l}\text { Household Income and utilization to } \\
\text { health service }\end{array}$ & OR. 1.02, 95\%, CI (1.01-1.03) & Suci, 2006 \\
\hline $\begin{array}{l}\text { Weekly household expenditure on food } \\
\text { OR. 0.998, 95\%, CI (0.997-0.998). }\end{array}$ & $\begin{array}{l}\text { Semba et al., 2008 } \\
\text { On animal source: } \\
\text { OR. 0.87, 95\%, CI }(0.85-0.90)\end{array}$ & Sari et al., 2010 \\
\hline
\end{tabular}

Note: OR=Odd Ratio

The statistical evidence is important for scientific studies, but the lay communities do not understand the meaning of the numbers. Academic journals also present how researches produce the evidence through rigour methods and the use frameworks. Generally, Indonesian researchers use methods, such as interview, observation, laboratory test, the food frequency questionnaire to investigate the causes of child malnutrition. They also use the secondary data from previous researches, such as the nutritional surveillance system and Central Statistical Bureau of the impact of the monetary crisis. The common framework that is used to analyse the causes of child malnutrition in Indonesian is the UNICEF's conceptual framework on the causes of malnutrition 1998. The new WHO child growth standards 2006 are also used to measure child nutritional status. Therefore, knowledge that is presented by academic journals is absolute, valid and reliable. On the other hand, media provide insufficient evidence of the causes of child malnutrition. Arguments about the causes of child malnutrition are based on opinions that are expressed by several experts and politicians, such as nutritionists, heads of health department, local legislative members and women organizations. The evidence is also obtained from mothers' expressions. Sometimes, pictures are used as the evidence of the existence of child malnutrition.

Media also use the research data from Indonesian health and demographic survey and the basic health research. Unfortunately, media do not provide the framework to analyse the cause of child malnutrition. The causes of child malnutrition are presented in the simple and common language. The authors present the cases from all representative regions in Indonesia, including Jawa, Sulawasi, Sumatra, Nusa Tenggara, Bali and Kalimantan Islands. The Jakarta Post, Tempo magazine and Metrotvnews have acted better as the senders messages to public. These media present the causes of Indonesian children malnutrition based on events that is occurring. For example, in the 2006s, these media portrayed economic deprivation or poverty as the basic cause of malnutrition in children under five. At that time, Indonesia experienced the economic crisis that increased poverty at the local, community and household level. While in the 2008s, in particular areas in East 
Nusa Tenggara and East Jawa provinces experienced the long drought. This condition affected significantly to child nutritional status. Thus, in the 2008s, media presented the long drought as the new basic cause of child malnutrition. This knowledge was also adapted from a scientific study conducted by Bardosono and others (Bardosono,. Sastroamidjojo, \& Lukito, 2007). Therefore, messages that are presented by media are acceptable, although its arguments are supported with insufficient evidence. Importantly, these three media use the lay language that can be understood by public. Furthermore, The Jakarta Post, Tempo magazine and Metrotvnews support and complement each other to present the causes of child malnutrition. For example, in 2012, Metrotvnews presents the causes in relation to economic deprivation, child morbidity, injustice of poor families, and inappropriate childcare practices (Metrotvnews, 2011; Metrotvnews, 2012). Tempo magazine then emphasizes child morbidity as a significant predictor of child malnutrition (Khafid, 2011). While The Jakarta Post supports other media with presenting the causes, such as maternal education, poverty, injustice of poor families, lack of access to health services and poor sanitation (Fointuna, 2008; Wihardja, 2012).

Moreover, these media also play as a mediator between the poor families and the authorities. For example, Metrotvnews presents an expression from a poor mother with a malnourished child in a hospital. The mother said that her child did not get maximum treatment because of no enough money to pay hospitalization (Metrotvnews, 2011). Several recommendations to the government also are presented in these media. For example, the provincial governments must build the roads to increase investment in poor areas (Nurhayati, 2008). Therefore, these three media can be said as a good policy advice as suggested by Althaus and others (Althaus, Bridgman, \& Davis, 2007). The reasons are that these three media have used lay languages, succinct forms and provide proper recommendations to the authorities.

\section{CONCLUSION}

In general, both academic literatures and media suggest the basic causes of child malnutrition encompass economic deprivation, low parental education, contradictory local traditional beliefs and long drought. These causes then influence households in purchasing power for food, providing appropriate foods, housing condition, utilization of child health care, parental awareness and knowledge about child nutrition. These underlying causes, eventually, lead to high child morbidity, low birth weight and low child nutritional intake. The way of presenting those causes is different between academic journals and media. Academic journals present the causes with use the statistical evidence, logical framework to analysis and good structures. Academic journals also describe what methods that are used to find out the knowledge about the causes of child malnutrition.

While media present the causes with the simple way, without frameworks and insufficient evidence. The causes of child malnutrition are gotten from experts and politicians' opinions and mothers' expressions. However, media present their cases from all representative regions of Indonesia, such as Jawa, Sumatra, Sulawesi, Kalimantan, Nusa Tenggara, and Bali Islands. Thus, media are viewed as an appropriate tool to push the issues into the policy agenda. Other important role of media is they can provide the knowledge about appropriate strategies to overcome child malnutrition. This knowledge can be gotten from the scientific studies around the world. 


\section{ACKNOWLEDGEMENT}

My sincere and special thanks go to the Indonesian Government, especially for Ministry of Research, Technology and Higher Education Degree for finance support for presentation in Indonesia. Also, I am very grateful to the heads and administrative staff at Mandala Waluya Health Science College who gave me an opportunity to present this study.

\section{REFERENCES}

Althaus, C., Bridgman P., \& Davis G., (2007). The Australian policy handbook., Sydney: Allen and Unwin.

Bardosono, S., S. Sastroamidjojo, \& W. Lukito, (2007) .Determinants of child malnutrition during the 1999 economic crisis in selected poor areas of Indonesia. Asia Pacific Journal of Clinical Nutrition, 16(3): p. 512-526.

Fointuna, Y., (2008). Malnutrition hits many parts of West Timor, in The Jakarta Post., The Jakarta Post: Jakarta.

Indonesian Health Department, (2011). Indonesian Health Profile 2010.: Jakarta.

Keleher, H. \& C. MacDougall (2011), Understanding health., South Melbourne, Victoria: Oxford University Press.

Khafid, S., (2011). Severe underweight children NTB influenced by parental child care behaviour, in Tempo., Tempo: Jakarta.

Li, J.,, (2009). Social determinants of child health and well-being. Health Sociology Review, . 18(1): p. 3-11.

Methotvnews, (2011). 36 under five children in Dompu suffer from severe underweight, Television Broadcast, Editor..

Metrotvnews, (2012). 891 under five children in NTB suffer from severe underweight, T. broadcast, Editor..

Metrotvnews, (2007). Koja hospital nurses two severe underweight children, T. broadcast, Editor..

Nugraha, P., (2012). 900 West Nusa Tanggara children suffer from malnutrition, in The Jakarta Post., The Jakarta Post: Jakarta.

Metrotvnews, (2012). Eleven under five children in Tuban suffer from severe underweight, T. broadcast, Editor..

Nurmiati \& Besral, (2008). The effect of duration of breastfeeding for infant immunity in Indonesia. Makara Kesehatan, 12(2): p. 47-52.

Oddo, V.M.,(2012)., Predictors of maternal and child double burden of malnutrition in rural Indonesia and Bangladesh. The American Journal of Clinical Nutrition, 95(4): p. 951-958.

Rurit, B., (2009). 23 under five children suffer from severe underweight in Kulon Progo, in Tempo., Tempo: Jakarta.

Priyasidharta, D., (2010). ,The government of Lumajang fails to reduce the prevalence of severe underweight, in Tempo. Tempo: Jakarta.

Sari, M., (2010), Higher Household Expenditure on Animal-Source and Nongrain Foods Lowers the Risk of Stunting among Children 0-59 Months Old in Indonesia: Implications of Rising Food Prices1-3. The Journal of Nutrition, 140(1): p. 195200. 
Semba, R.D., (2008).., Effect of parental formal education on risk of child stunting in Indonesia and Bangladesh: A cross-sectional study. The Lancet, 371(9609): p. 322328.

Seo, Y., (2010). 3 severe underweight children in South Central Timor died this month, in Tempo., Tempo: Jakarta.

Siswadi, A., (2010). Thousand under five children in West Java severe underweight, in Tempo., Tempo: Jakarta.

Smith, L. C., \& Haddad, L. (2000). Explaining child malnutrition in developing countries: A cross-country analysis. Washington, D.C: International Food Policy Research Institute. 